
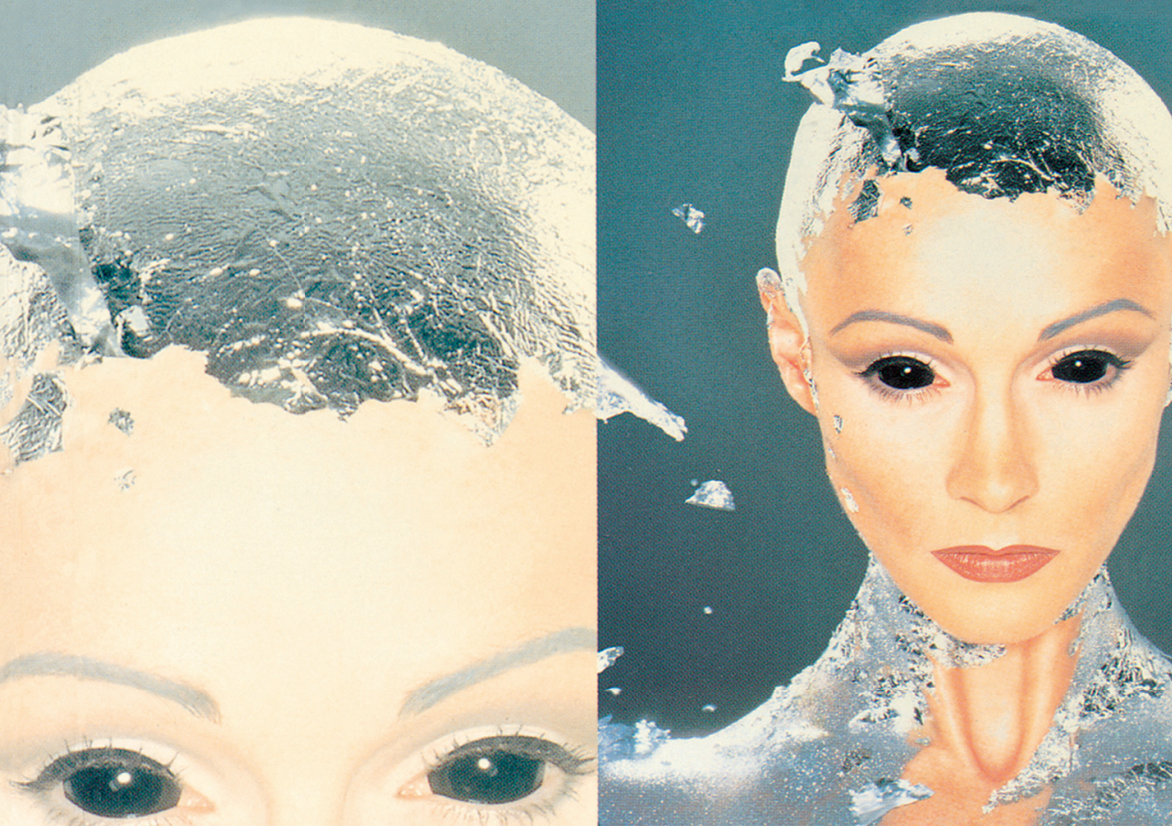


\section{Gothic forms \\ of feminine fictions}


Susanne Becker - 9781526125378

Downloaded from manchesterhive.com at 04/26/2023 03:10:32PM

via free access 


\title{
Gothic forms \\ of feminine fictions
}

Susanne Becker

\author{
MANCHESTER \\ UNIVERSITY PRESS \\ Manchester
}


Copyright (C) Susanne Becker 1999

The right of Susanne Becker to be identified as the author of this work has been asserted by her in accordance with the Copyright, Designs and Patents Act 1988 .

Published by Manchester University Press

Altrincham Street, Manchester, M1 7JA, UK

wWw.manchesteruniversitypress.co.uk

British Library Cataloguing-in-Publication Data

A catalogue record for this book is available from the British Library

Library of Congress Cataloging-in-Publication Data

A catalog record for this book is available from the Library of Congress

ISBN 9780719053313 paperback

ISBN 9781526125378 Institutional

First published by Manchester University Press 1999

First digital paperback edition published 2012

The publisher has no responsibility for the persistence or accuracy of URLs for any external or third-party internet websites referred to in this book, and does not guarantee that any content on such websites is, or will remain, accurate or appropriate. 